\title{
APPLICATION OF THE LIFEROSE METHOD IN FUNCIONALITY EVALUATION OF ROAD SAFETY EQUIPMENT
}

\section{Zastosowanie metody LifeRoSE do oceny funkcjonalności drogowych środków brd}

\begin{abstract}
The article presents a mathematical model of the life cycle estimation method of road safety equipment. Then the model was adjusted to estimate the life cycle costs of the chosen horizontal road marking. Using the LCC method, the functionality of the horizontal marking was evaluated in terms of efficiency, durability and economic effectiveness. The article also presents the impact of selected factors on the life cycle costs of the horizontal road marking.
\end{abstract}

Keywords: LCC method, functionality, durability, road safety equipment

Streszczenie: Wartykule zaprezentowano matematyczny model metody szacowania kosztów cyklu życia drogowych środków brd. Następnie model ten zostat dostosowany do oszacowania kosztów cyklu życia wybranego oznakowania poziomego. Za pomoca metody LCC oceniono funkcjonalność oznakowania poziomego pod względem wydajności trwałości $i$ efektywności ekonomicznej. W pracy przedstawiono również wpływ wybranych czynników na całkowite koszty cyklu życia oznakowania poziomego.

Słowa kluczowe: metoda LCC, funkcjonalność, trwałość, drogowe środki brd 


\section{Introduction}

The level of functionality of individual elements of the road transport system (human - vehicle - road) affects the risk of participating in an accident. One of the consequences of the malfunctioning system is the vehicle run-off-road (ROR) crash. In order to protect vehicles and pedestrians from ROR events, road safety equipment is applied. Road safety equipment RoSE is divided into two groups: road safety devices - RSD (e.g. road safety barriers) and road traffic management devices - TMD (e.g. signs and horizontal road markings). RSD is used to protect the lives and, to a limited extent, the property of traffic participants. Whereas, TMD are applied to the organisation and control of road traffic and to inform about possible dangers.

Properly designed road safety equipment should meet many functional properties, e.g. safety, durability, efficiency and economic effectiveness [4]. However, very often, the choice of a given road safety equipment is determined by the economic aspect - the amount of initial costs of the facility. Road safety equipment are complex objects, the functionality evaluation of which should cover their entire life cycle. Making decisions only on the basis of the initial costs may negatively affect the functionality of the facility at a later stage of its life [5].

The life cycle cost estimation method (LCC method) allows us to assess the functionality of an object at every stage of its life. In Poland, the conditions for using LCC analysis are specified in the standard: PN-EN 60300-3-3:2014 [16]. However, in [16], only general frameworks and procedures for conducting LCC cost estimation are defined, which cannot be directly applied to the assessment of the functionality of road safety equipment. As a part of a RID 3B research project conducted at the Gdansk University of Technology in the years 2016-2018, entitled 'Impact of time and operating conditions on the durability and functionality of road safety equipment', a method for estimating and analysing the life cycle costs of road safety equipment LifeRoSE (Life Cost Analysis of Road Safety Equipment), has been developed. This method can be applied in Poland. For the purposes of this article, one of the simplest elements of the road maintenance process has been selected - horizontal road markings.

The purpose of the work is:

1. to present the principle of functioning the LifeRoSE method and its application for traffic management,

2. to present the possibility of applying the LifeRoSE method to the studies on the impact of a set of selected factors on the life cycle costs of selected types of road horizontal road markings. 


\section{Life cycle costs estimation method}

\subsection{Development of LCC methods}

Life cycle cost estimation method (LCC) is a process of economic analysis aimed at assessing the cost incurred by the investor and users of the analysed object (product) during its life cycle [16].

The first application of the LCC method by the US Ministry of Defence took place in the late 1960s. At that time, the LCC calculation was applied to several levels of activity of the American army, including the operation of the means of transport. In the $1980 \mathrm{~s}$, the method was popularized, which resulted in the publication of several guides on its application. Over time, LCC analysis began to spread to other industries such as aviation, energy, oil, chemical, transport and construction [17]. In the case of road safety equipment, the LCC method for road safety devices has been used, inter alia, in the UK to estimate the costs of median steel and concrete barriers [18], in Sweden to estimate the costs of W-beam, cable and concrete barriers [8]. The LCC method was also applied in the selection of the type of road markings in the USA [19].

Essential for the application of the LCC method is the understanding of the durability cycle and activities undertaken in the subsequent phases of the facility cycle. The life cycle of a facility means here the full range of time, from the creation of the facility concept to its decommissioning. The cost of the life cycle is the total capital used during this period. According to [16], it is recommended to select the appropriate phases of the life cycle, their parts or combinations, in order to adapt the LCC method to the needs of the analysis of the facility functionality. In road facilities, there are five basic phases of the life cycle, i.e. planning, design, construction, maintenance and decommissioning [4]. The level of life cycle costs and functionality of the facility is formed in all phases of its creation and maintenance.

\subsection{Measures of functionality}

The functionality of road safety equipment is defined as the ability of such equipment to operate 24 hours a day, 365 days a year. The continuity of operation of these devices is a feature which consists in the constant provision of appropriate quality parameters for the transmission and reception of information, driving, safety, etc. to road users [6]. Providing the user with the expected level of object functionality entails certain expenses [3], which can be estimated by the LCC method. The functionality of an object can be assessed on the basis of functions such as durability, safety, efficiency and economic effectiveness.

Durability is defined as the ability to maintain the properties assumed by the user for a specific time and under specific operating and environmental conditions. In the case of road markings, this property will be their visibility. Until now, many research teams have tried to determine the durability of horizontal road markings. The most frequently mentioned factors affecting the durability of road markings include traffic volume and its structure $[9,10,12,15]$, the frequency of snowfall and the related activity of snow ploughs 
$[9,12-15]$, the type, quality of the material used for horizontal road markings, technical and usable condition of the ground - the road surface, abrasive road surface $[10,12,14]$ and the location of the markings (road centre, roadside) $[12,14]$ and the overrun frequency. Such a large number of factors influencing the durability of horizontal markings makes the determination of its lifetime a significant research problem. Foreign experience shows that in the case of horizontal markings, the life cycle length was adopted and modelled in various ways. Fixed values were adopted depending on the type of material used, and road marking thickness [2], or models predicting the lifespan of horizontal road markings were built [1].

Safety, in terms of road safety, is understood as ensuring such a state which can reduce to the minimum the consequences resulting from improper behaviour of road users. So far, the impact of the use of horizontal markings on the road safety condition has been studied. Among other things, the influence of the location of horizontal signs on the road on the reduction of accidents has been studied. For example, the use of edge lines may contribute to the reduction of accidents in the USA from $3 \%$ to $60 \%$, in the UK from $18 \%$ to $30 \%$; and the use of central lines may contribute to the reduction of accidents from 10 to $29 \%$ [11]. The assessment of marking safety due to the material used is quite a complex task. This fact makes the analysis of road accident costs in the LCC quite often omitted [19].

Efficiency (capacity) can be estimated by traffic delay costs resulting from the need to renew the horizontal marking. The traffic delay costs during the application of horizontal road markings, which are due to capacity constraints (closure of some road lanes) in the LCC analysis were used, among others, in Zhang's work [19]. However, the variability of the unit time loss depending on the type of horizontal marking was omitted.

Economic effectiveness is the ability to use resources in such a way as to achieve a given objective in the most efficient and least wasteful way. Economic effectiveness can be assessed by means of net present value, internal rate of return or benefit-cost analysis, which was used in the horizontal marking [11]. The use of benefit-cost analysis (benefit-cost ratio, $\mathrm{BCR})$ in [11] allowed us to estimate the benefits of using the thermoplastic markings (BCR=130; urban area).

\subsection{General model of LifeRoSE method}

The RID 3B research project LifeRoSE has developed an overall concept for a method for estimating the life cycle costs of road safety devices on national roads.

The method is based on a simple mathematical model for Life Cycle Costing (LCC) estimation of road safety equipment described by formula (1). Also, the structure of division of LCC costs of road safety equipment was adopted and presented in fig. 1

$$
L C C=K S+\sum_{i=1}^{T} \frac{K Z_{i}}{(1+a)^{T}}
$$

where:

$L C C$ - life cycle costs of functioning of road safety equipment, $K S$ - fixed costs, $K Z$ - variable costs, $a$ - discount rate, $i$ - analysis year, $T$ - time period (lifespan). 
Fixed KS costs are expenses incurred in the first life cycle of a facility, i.e. expenses incurred by the investor (road authority) for development, purchase of materials and installation of road safety equipment on the analysed road. On the other hand, variable KZ costs are the expenditures incurred for the maintenance of the road safety equipment and the costs of the road users related to the maintenance of the equipment in subsequent years of the facility's life. The developed method may be used to estimate the costs of functioning of the analysed road safety equipment (road barriers, horizontal markings, etc.) in the life cycle of the analysed road section depending on a set of parameters describing its particular functionality measures such as durability, efficiency, safety and economic efficiency.

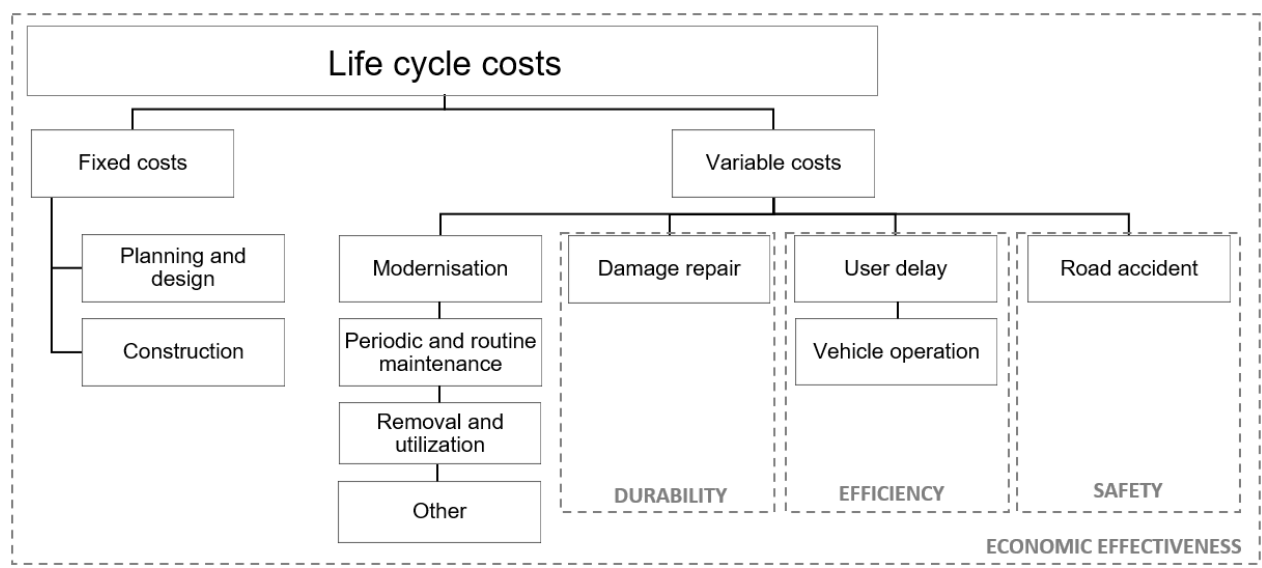

Fig. 1. Components of road safety equipment life cycle costs and functionality measures

The durability is assessed by the cost of repairing damage (renewal) to the road safety equipment. These costs are generated in the case of road safety equipment and signs as a result of the vehicle ROR, while in the case of horizontal markings, there are the costs associated with the need to renew the device due to the loss of minimum functional parameters.

The efficiency of road safety equipment was determined by the traffic delay costs and vehicle operating costs. The traffic delay costs are caused by hitting the road safety devices or occupying a road lane due to the renewal of markings. Vehicle operating costs are the additional costs of fuel consumption and vehicles resulting from the extension of travel time due to the accident.

Safety is estimated by accidents costs, which can be defined as the costs that are incurred as a result of an incident with road safety equipment and its consequences. 


\section{Application of the LifeROSE method to evaluate the functionality of road horizontal markings}

Proposed method. The LifeROSE method has been adapted to the estimation of the costs of functioning of road horizontal markings by omitting the following cost components: periodic and routine maintenance costs, vehicle operating costs, accident costs and removal costs, due to the limited scope of data concerning road markings in the available data. The LCC model of road markings after the development of the LifeROSE method formula (1), takes the form described in formula (2):

$$
L C C_{m}=K_{p l}+K_{b u}+\sum_{i=1}^{T} \frac{K_{n a_{i}}+K_{s t_{i}}}{(1+a)^{T}}
$$

where:

$L C C m$ - life cycle costs of functioning of horizontal marking in the analysed road section, $K p l$ - planning and design costs, $K b u$ - application (construction) costs, Kna - renewal (repair) costs, $K s t$ - traffic delay costs , $a$ - discount rate, $i-$ analysis year, $T$ - analysis period

Research methodology. The LifeROSE method was used to assess the functionality of the horizontal marking. For analytical studies, the following assumptions were made:

1. The object of the study was a $1 \mathrm{~km}$ long section of an expressway, where horizontal marking in the form of a continuous edge lines was applied.

2. Four types of horizontal road markings have been adopted, made of:

a) thermoplastic material with micro glass beads proportion $<30 \%$,

b) thermoplastic material with micro glass beads proportion $>30 \%$,

c) 2-component cold plastic material (application - spray method),

d) 2-component cold plastic material (application - extrusion method).

3. The average daily traffic volume of vehicles (AADT) is set to be $10,000 \mathrm{veh}$./day per lane.

4. The average durability period $\left(\mathrm{TR}_{\mathrm{m}}\right)$ of particular types of markings was based on AADT and on the basis of the research conducted under the RID 3B project [7].

5. The current discount rate for the year 2019 was assumed, $\mathrm{a}=2.87 \%$.

6. The average time of application of markings on the road was assumed to be the duration of the event (to calculate the time loss of road users).

7. It was assumed that the renewal (repair) costs are equal to the application costs

8. The lifespan of the road section $\mathrm{T}=30$ years was set.

Two indicators have been adopted to assess the economic efficiency of selected types of horizontal marking:

1. the functionality costs of the selected types of horizontal markings $\mathrm{LCC}_{\mathrm{m}}$,

2. economic efficiency index $\mathrm{WE}_{\mathrm{m}, \mathrm{i}}$ calculated with formula (3): 


$$
W E_{m, i}=\frac{L C C_{m, i}}{L C C_{m, \min }}
$$

where:

$W E m, i-$ economic efficiency index of the i-th type of horizontal marking, $L C C m, i-$ the life cycle costs of the i-th type of horizontal marking, $L C C m, \min$ - minimum life cycle costs, $i$ - type of horizontal marking.

The results of calculations for the values adopted in the assumptions for testing are presented in table 1 .

Table 1

\section{Life cycle costs of horizontal markings}

\begin{tabular}{|c|c|c|c|c|c|c|}
\hline $\begin{array}{c}\text { Type of } \\
\text { material } \\
\mathrm{i}\end{array}$ & $\begin{array}{c}\text { Expected } \\
\text { durability } \\
\mathrm{TR}_{\mathrm{m}}\end{array}$ & $\begin{array}{c}\text { Life cycle } \\
\text { costs } \\
\text { LCC }\end{array}$ & $\begin{array}{c}\text { Installation } \\
\text { costs } \\
\mathrm{K}_{\mathrm{pl}}+\mathrm{K}_{\mathrm{bu}}\end{array}$ & $\begin{array}{c}\text { Renewal } \\
\text { costs } \\
\mathrm{K}_{\mathrm{na}}\end{array}$ & $\begin{array}{c}\text { Traffic delay } \\
\text { costs } \\
\mathrm{K}_{\mathrm{st}}\end{array}$ & $\begin{array}{c}\text { Economic } \\
\text { efficiency } \\
\text { index } \\
\mathrm{WE}_{\mathrm{m}}\end{array}$ \\
\cline { 2 - 7 } & (years) & $\begin{array}{c}\text { (thous. PLN/30 } \\
\text { years) }\end{array}$ & $\begin{array}{c}\text { (thous. PLN/301 } \\
\text { yeras) }\end{array}$ & $\begin{array}{c}\text { (thous. PLN/30 } \\
\text { years) }\end{array}$ & $\begin{array}{c}\text { (thous. PLN/30 } \\
\text { years) }\end{array}$ & $(-)$ \\
\hline $\mathrm{a}$ & 3 & 39.0 & 5.2 & 33.5 & 0.3 & 1.2 \\
\hline $\mathrm{b}$ & 4 & 32.5 & 5.8 & 26.5 & 0.2 & 1.0 \\
\hline $\mathrm{c}$ & 1 & 110.2 & 5.0 & 98.4 & 6.8 & 3.4 \\
\hline $\mathrm{d}$ & 2 & 82.3 & 7.4 & 72.8 & 2.1 & 2.5 \\
\hline
\end{tabular}

Based on the analysis performed, it was concluded that:

1. the lowest life cycle costs of $\operatorname{LCC}_{m}$ (32.5 thousand PLN) and the best economic efficiency index $\left(\mathrm{WE}_{\mathrm{m}}=1.0\right)$ are characteristic for the section of the analysed road where the marking was made of thermoplastic material with micro glass beads proportion $>30 \%$; therefore it is the material recommended for application for the example given above; this road is also characterized by efficiency and the mass is durable,

2. the highest costs of the $\mathrm{LCC}_{\mathrm{m}}$ life cycle (110.2 thousand PLN) and the worst economic efficiency index $\left(\mathrm{WE}_{\mathrm{m}}=3.4\right)$ are characteristic for the section of the analysed road, where the marking was made of the cold two-component marking. Although it is the cheapest in the application, it has low durability and generates large time losses for road users, so it is not a type recommended for application for the analysed road section,

3. renewal costs account for about $90 \%$ of life cycle costs. 


\section{Study of the impact of selected factors on life cycle costs of a road section with a selected type of horizontal marking}

In the previous chapters, it was shown that the type of horizontal road marking has a significant impact on the life cycle cost of the analysed road section. This chapter presents the results of studies on the influence of selected factors: the amount of discount rate $a$, the road traffic volume AADT and durability of marking (lifespan) $\mathrm{TR}_{\mathrm{m}}$. The LifeRoSE method was also used for analytical studies, assuming the following additional assumptions:

1. Two types of horizontal marking have been selected:

a) To study the effect of discount rate $a$ and road traffic volume AADT the 2-component cold plastic material (application - spray method), was used (No. 3 in the previous study),

b) The thermoplastic material with micro glass beads proportion $<30 \%$, (No. 1 in the previous study) was used to examine the impact of lifespan (durability) $\mathrm{TR}_{\mathrm{m}}$ on $\mathrm{LCC}_{\mathrm{m}}$.

2. Annual average daily traffic AADT was set in the range 5,0 and 20,0 thous. veh/day (road lane).

3. An average lifespan (durability) $\mathrm{TR}_{3}=1$ year, $\mathrm{TR}_{1}=2-4$ years is assumed.

4. A discount rate $a$ between $1.0-6.0 \%$ is assumed.

5. Other assumptions were made similar to those in the previous analysis (Chapter 3)

The results of the study indicate that the increase in the discount rate affects the decrease in the life cycle costs $\mathrm{LCC}_{\mathrm{m}}$ of the analysed road section marked with the cold twocomponent marking (fig. 2). The higher the discount rate, the smaller the range of costs is adopted for assessment (the higher the weight is adopted for the initial analysis period). This is important for longer analysis periods, e.g. life cycle costs in the 10th year of functioning of the analysed road section with the cold two-component marking differ by about $15 \%$ and in the 30 th year by about $40 \%$. 


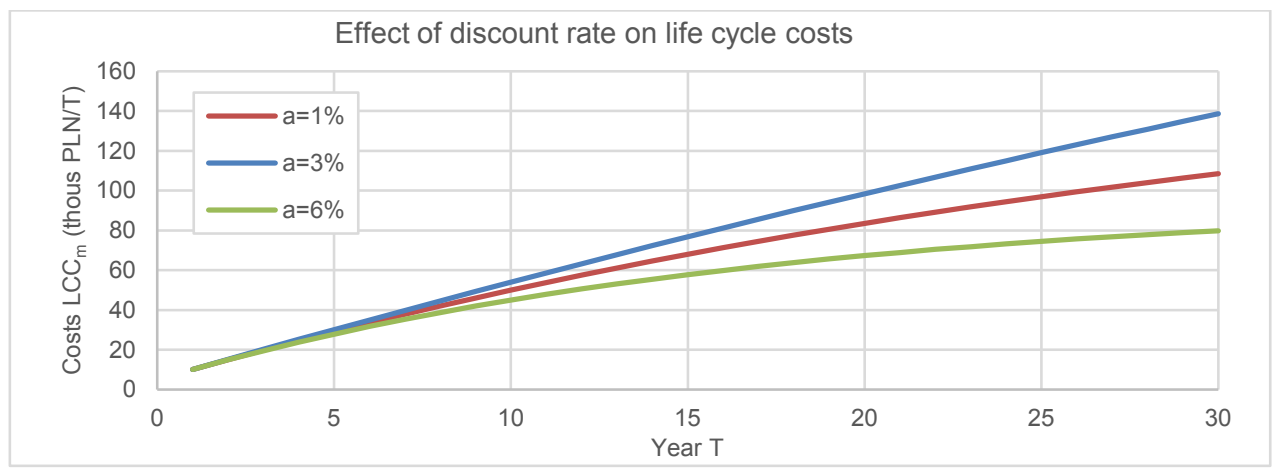

Fig. 2. Effect of discount rate $a$ and time period T on life cycle costs $\mathrm{LCC}_{\mathrm{m}}$ of the cold two-component marking

An AADT increase contributes to an increase in $\mathrm{LCC}_{\mathrm{m}}$ of road section with the cold two-component marking (spray method) (fig. 3). With the increase in the volume of traffic vehicles, the durability (lifespan) of road marking decreases. The traffic delay costs $\mathrm{K}_{\mathrm{st}}$ (during the renewal) increase. The study concluded that the traffic delay costs have a low impact on the life cycle costs in the case of renewal of marking during low traffic volume (approx. 5\% of total costs). On the other hand, with higher traffic volume AADT $>10$ thous. $\mathrm{veh} /$ day, the percentage of traffic delay costs increases rapidly and may constitute a factor that determines the amount of life cycle costs of a road section with horizontal marking.

The increase in $\mathrm{TR}_{\mathrm{m}}$ lifespan (durability) has an influence on the reduction of life cycle costs $\mathrm{LCC}_{\mathrm{m}}$ of the road section with a thermoplastic material with micro glass beads proportion $<30 \%$ (fig. 4). With the increase in the durability of markings, the frequency of horizontal marking application on the road and of road closures (lower time loss) is decreased.

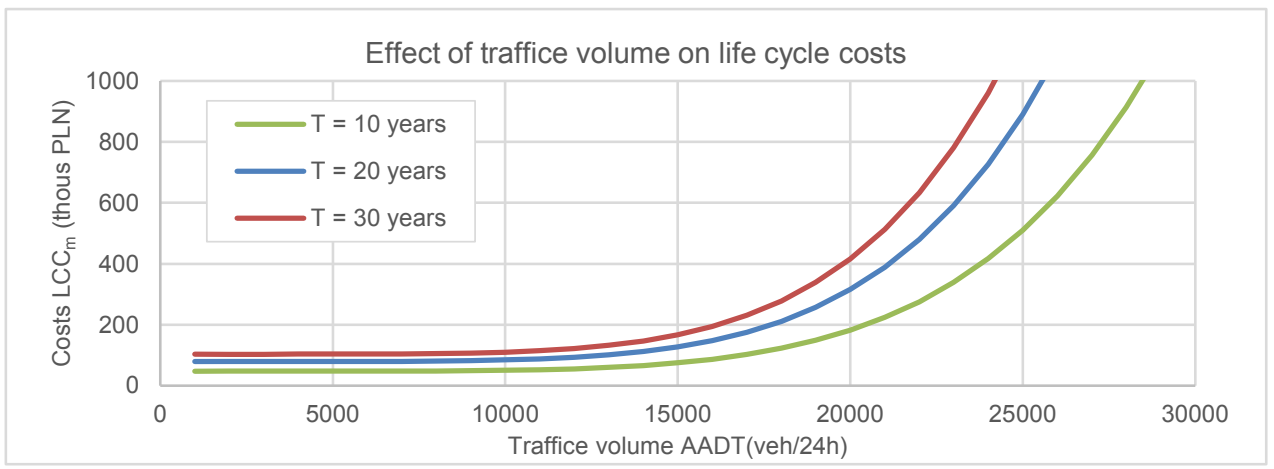

Fig. 3. Effect of traffic volume and life cycle period $\mathrm{T}$ on life cycle costs $\mathrm{LCC}_{\mathrm{m}}$ of the cold twocomponent marking 


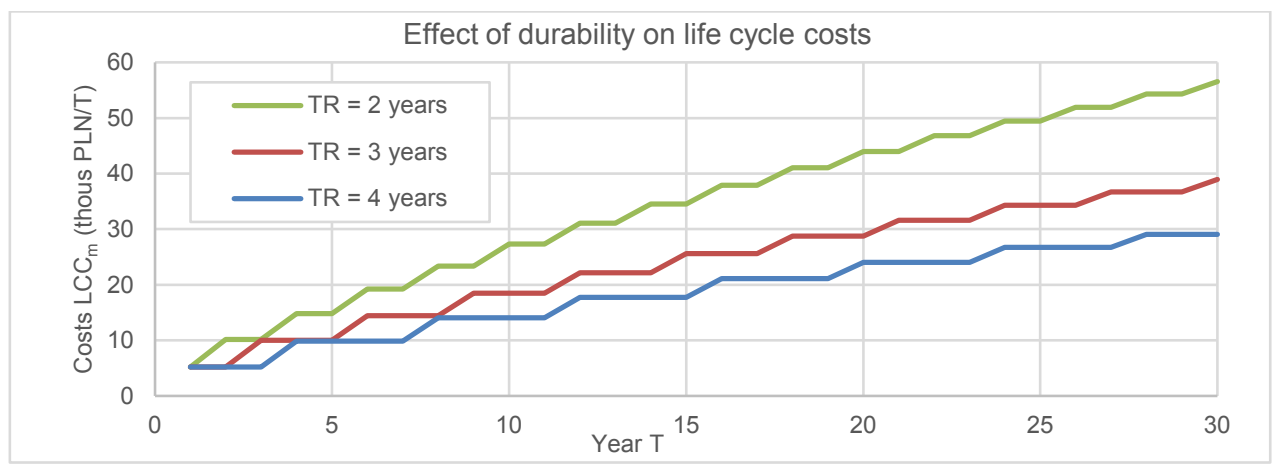

Fig. 4. Effect of durability $T R_{m}$ and time period $T$ on life cycle costs $L_{C C}$ of thermoplastic material.

To simplify the analysis, an average lifespan (durability) $\mathrm{TR}_{\mathrm{m}}$ was assumed in the study, regardless of the vehicle traffic volume under analysis. In fact, the lifetime of horizontal markings depends on the traffic volume, and in particular, on the number of vehicle wheel passages on the road surface with the markings applied. Moreover, as shown in the literature review, many other parameters affect the durability period. If the $\mathrm{LCC}_{\mathrm{m}}$ method is used to select a particular type of material, the quality of the materials should be verified and the conditions under which they will function should be determined in order to determine their durability.

\section{Conclusions}

The life cycle cost estimation method enables us to combine the economic, technical and functional aspects of the object under assessment and is a good tool to assess the functionality of road safety equipment. It enables us to compare the selected utility functions - durability, efficiency and safety of selected road structures by means of costs.

The presented LifeRoSE method is universal and can be used to estimate the life cycle costs of road sections and to assess the economic efficiency of selected brd road safety measures used on the analysed road. It allows us to choose the optimal solution in terms of functionality.

The LifeRoSE method can be used as a research tool to study the influence of selected factors on the change of life cycle costs.

The accuracy of estimation of life cycle costs of the analysed object involves collecting a large set of data on partial costs of construction and operation of individual elements of the object. Dependency models of these costs on the size of particular factors that influence the functioning of the analysed object, such as, e.g. durability, traffic safety, time loss, can be helpful.

In further works, it is envisaged to develop such models and to take into account the impact of changes in the quality of road markings on road traffic safety as well as to include 
this factor in the road operation costs with the use of horizontal markings made of various materials.

\section{References}

1. Babić D., Ščukanec A., Babić D., Fiolić M.: Model for predicting road markings service life. Baltic Journal of Road and Bridge Engineering, vol. 14, no. 3, 2019.

2. Dz.U. 2003 nr 220 poz. 2181, Rozporządzenie Ministra Infrastruktury w sprawie szczegółowych warunków technicznych dla znaków i sygnałów drogowych oraz urządzeń bezpieczeństwa ruchu drogowego i warunków ich umieszczenia na drogach.

3. Dziaduch I.: Analiza kosztów okresu istnienia (LCC) obiektu technicznego w aspekcie jego niezawodności. Logistyka, rocznik 2011, nr 2, 2011.

4. Jamroz K.: Metoda zarządzania ryzykiem w inżynierii drogowej, Gdańsk 2011.

5. Jamroz K., Gobis A., Kristowski A., Grzyl B.: Proposed method for estimating the costs of safety barrier life cycle. MATEC Web of Conferences, vol. 231, 2018.

6. Jeliński Ł., Jamroz K., Jamroz J., Antoniuk M.: Functionality of road safety devices - identification and analysis of factors. MATEC Web of Conferences, vol. 122, 2017.

7. Jeliński L., Wachnicka J., Jamroz J., Kalisz M., Kaźmierczak P., Lusa R., et al.: Testing the durability and function of road traffic management devices. MATEC Web Conferences, vol. 122, 2017.

8. Karim H., Magnusson R., Natanaelsson K.: Life-Cycle Cost Analyses for Road Barriers. Journal of Transportation Engineering, vol. 138, iss.7, 2012.

9. Kopf J.: Reflectivity of Pavement Markings: Analysis of Retroreflectivity Degradation Curves, 2004.

10. Malyuta D.A.: Analysis of factors affecting pavement markings and pavement marking retroreflectivity in Tennessee Highways, University of Tennessee, 2015.

11. Miller T.R.: Benefit-cost analysis of lane marking. Transportation Research Record, 1334, 1993.

12. Monfette M.: Impact of snow removal operations on thermoplastic pavement markings, Air Force Institute of Technology, 2011.

13. Mull D.M., Sitzabee W.: Paint Pavement Marking Performance Prediction Model. Journal of Transportation Engineering, vol. 138, 2012.

14. Needham J.: Degradation modeling of polyurea pavement markings, Air Force Institute of Technology, 2011.

15. Onyango M.A., Malyuta D., Owino J., Chimba D.: Verification of pavement marking degradation models using eastern Tennessee pavement marking retroreflectivity data. 2nd Pan African Int. Conf. Sci., Comput. and Telecommun, 2014 . 
16. PN-EN 60300-3-3, Zarządzanie niezawodnością część 3-3: Przewodnik zastosowań Szacowanie kosztu cyklu życia, 2017.

17. Tułecki A., Szkoda M.: Koszt trwałości LCC jako model decyzyjny modernizacji pojazdów szynowych. Zeszyty Naukowe Instytutu Pojazdów, z.1/64, 2007.

18. Williams G.L.: Whole Life Cost-Benefit Analysis for Median Safety Barriers. Task 1-Relocation of service, 2007.

19. Zhang Y., Wu D.: Methodologies to Predict Service Lives of Pavement Marking Materials. Journal of the Transportation Research Forum, vol. 45, no. 3, 2006. 


\section{ZASTOSOWANIE METODY LIFEROSE DO OCENY FUNKCJONALNOŚCI DROGOWYCH ŚRODKÓW BRD}

\section{Wprowadzenie}

Poziom funkcjonalności poszczególnych elementów systemu transportu drogowego (człowiek - pojazd - droga) wpływa na ryzyko uczestniczenia w wypadku. Jedną z konsekwencji nieprawidłowego działania systemu jest wypadnięcie pojazdu z drogi. W celu zabezpieczania środka transportu oraz pieszych przed tego rodzaju zdarzeniami stosuje się drogowe środki bezpieczeństwa ruchu drogowego (brd) RoSE. Dzieli się je na dwie grupy: urządzenia bezpieczeństwa ruchu drogowego RSD (np. drogowe bariery ochronne) i środki organizacji ruchu drogowego TMD (m.in. oznakowanie pionowe i poziome). RSD stosuje się w celu ochrony życia, a także mienia użytkowników drogi. Natomiast TMD używa się do zarządzania ruchem drogowym w szczególności: organizacji i sterowania ruchem drogowym oraz informowania użytkowników drogi o ewentualnych zagrożeniach.

Prawidłowo zaprojektowane drogowe środki brd powinny spełniać wiele właściwości funkcjonalnych m.in. bezpieczeństwo, trwałość, wydajność i efektywność ekonomiczną [4] . Jednak bardzo często o wyborze danego środka decyduje tylko aspekt ekonomiczny wysokość kosztów początkowych obiektu. Drogowe środki brd są to złożone obiekty, których ocena funkcjonalności powinna obejmować cały cykl ich życia. Podejmowanie decyzji jedynie na podstawie wysokości nakładów początkowych może wpłynąć w sposób negatywny na funkcjonalność obiektu w późniejszym etapie jego życia [5].

Metoda szacowania kosztów cyklu życia (metoda LCC) umożliwia ocenę użyteczności obiektu na każdym etapie. W Polsce warunki korzystania z analizy LCC precyzowane są w normie: PN-EN 60300-3-3:2014 [16]. Jednakże w [16] zdefiniowano jedynie ogólne ramy, a także procedury przeprowadzania szacowania kosztów metodą LCC, których nie da się w sposób bezpośredni zastosować do oceny funkcjonalności drogowych środków brd. W ramach projektu badawczego, przeprowadzonego na Politechnice Gdańskiej w latach 2016-2018, RID 3B „Wpływ czasu i warunków eksploatacyjnych na trwałość i funkcjonalność elementów bezpieczeństwa ruchu drogowego" opracowano metodę szacowania i analizy kosztów cyklu życia drogowych środków brd LifeRoSE (Life Cost Analysis of Road Safety Equipments), która może być stosowana w polskich warunkach. $\mathrm{W}$ artykule wybrano jeden $\mathrm{z}$ najprostszych elementów procesu utrzymania drogi oznakowanie poziome dróg.

Celem pracy jest: 
1. zaprezentowanie zasady funkcjonowania metody LifeRoSE i jej aplikacja do potrzeb zarządzania ruchem drogowym,

2. przedstawienie możliwości zastosowania metody LifeRoSE do badań wpływu zbioru wybranych czynników na wielkość kosztów cyklu życia wybranych rodzajów oznakowania poziomego dróg.

\section{Metoda szacowania kosztów cyklu życia}

\subsection{Rozwój metod LCC}

Szacowanie kosztu cyklu życia (LCC) jest to proces analizy ekonomicznej, mającej na celu ocenę kosztu ponoszonego przez inwestora i użytkowników analizowanego obiektu (wyrobu) w cyklu jego życia [16].

Metodę LCC pierwszy raz użyło Ministerstwo Obrony USA pod koniec lat 60. Wówczas kalkulacja LCC została zastosowania do kilku płaszczyzn działalności amerykańskiej armii m.in. do eksploatacji środków transportu. W latach 80. XX w. nastąpiła popularyzacja tej metody, poskutkowało to wydaniem kilku przewodników dotyczących jej stosowania. Z upływem czasu analiza LCC zaczęła rozpowszechniać się na inne gałęzie przemysłu np. w branży lotniczej, energetyce, branży naftowej, chemicznej, w transporcie i budownictwie [17]. W przypadku drogowych środków brd metodę szacowania kosztów cyklu życia zastosowano m.in. w Wielkiej Brytanii do oszacowania kosztów barier stalowych, a także betonowych zlokalizowanych w pasie dzielącym [18], w Szwecji do oceny kosztów barier dzielących stalowych, linowych oraz betonowych [8]. Metoda szacowania kosztów znalazła również zastosowanie przy wyborze rodzaju oznakowania drogowego w USA [19].

Zasadnicze znaczenie przy stosowaniu metody LCC ma zrozumienie cyklu trwałości i działań podejmowanych w kolejnych fazach cyklu obiektu. Cykl życia obiektu oznacza tutaj pełen przedział czasu od stworzenia koncepcji obiektu do jego likwidacji. Natomiast koszt cyklu życia to całkowity kapitał wykorzystany w trakcie tego okresu. Zgodnie z [16] zaleca się dokonanie wyboru odpowiednich faz cyklu życia, ich części albo kombinacji, w celu dostosowania metody LCC do potrzeb analizy funkcjonowania obiektu. W obiektach drogowych wyróżnia się pięć zasadniczych faz cyklu życia, tj. planowanie, projektowanie, budowa, eksploatacja oraz likwidacja [4]. Poziom kosztów cyklu życia i funkcjonalność obiektu formowana jest we wszystkich fazach jego powstawania i eksploatowania.

\subsection{Miary funkcjonalności}

Funkcjonalność drogowych środków bezpieczeństwa ruchu drogowego definiowana jest jako zdolność do działania tych środków przez 24 godziny na dobę i 365 dni w roku. Ciągłość działania tych środków jest cechą, która polega na stałym zapewnieniu 
użytkownikom drogi odpowiednich parametrów jakości przekazywania i odbioru informacji, prowadzenia pojazdu, bezpieczeństwa itp. [6]. Zapewnienie użytkownikowi oczekiwanego poziomu funkcjonalności obiektu pociąga za sobą określone wydatki [3], które mogą być oszacowane za pomocą metody LCC. Funkcjonalność obiektu można ocenić na podstawie takich funkcji jak: trwałość, bezpieczeństwo, wydajność i efektywność ekonomiczna.

Trwałość definiowana jest jako zdolność do zachowania założonych przez użytkownika właściwości przez określony czas, a także w określonych warunkach eksploatacyjnych i środowiskowych. W przypadku oznakowania drogowego taką właściwością będzie ich widoczność. Wiele zespołów próbowało określić żywotność oznakowania poziomego. Do najczęściej wymienianych czynników wpływających na trwałość oznakowania poziomego dróg należą: natężenie ruchu drogowego oraz jego struktura [9, 10,12,14,15], częstość opadów śniegu i związana z nimi działalność pługów śnieżnych [9, 12-15], rodzaj, jakość materiału stosowanego do jego wykonania, stan techniczny i użytkowy podłoża - warstwy jezdnej, ścieralnej nawierzchni drogowej [10, $12,14]$, a także lokalizacja oznakowania (środek drogi, pobocze) $[12,14]$ oraz związana z nią częstotliwość najeżdżania. Tak duża liczba czynników wpływających na trwałość oznakowania poziomego sprawia, iż określenie jego okresu żywotności stanowi znaczący problem badawczy. Doświadczenia zagraniczne pokazują, że w przypadku oznakowania poziomego długość cyklu życia była przyjmowana i modelowana w różnoraki sposób. Przyjmowano stałe wartości uzależnione od rodzaju zastosowanego materiału i grubości oznakowania [2] albo budowano modele prognozujące długość cyklu życia oznakowania poziomego [1].

Bezpieczeństwo, w ujęciu bezpieczeństwa drogowego, rozumie się jako zapewnienie takiego stanu, który potrafi zredukować do minimum konsekwencje wynikające z nieprawidłowego zachowania użytkowników dróg. Do tej pory badano, jaki wpływ ma stosowanie oznakowania poziomego na stan bezpieczeństwa ruchu drogowego. Przebadano m.in. wpływ usytuowania oznakowania poziomego na drodze na redukcję liczby wypadków, stosując linie krawędziowe można przyczynić się do redukcji liczby wypadków np. w USA od 3\% do 60\%, w Wielkiej Brytanii od 18\% do 30\%, a zastosowanie linii osiowych może przyczynić się do redukcji liczby wypadków od 10\% do 29\% [11]. Ocena bezpieczeństwa oznakowania $\mathrm{z}$ uwagi na zastosowany materiał jest zadaniem dość złożonym. Fakt ten sprawia, że analiza kosztów zdarzeń w metodzie LCC jest dość często pomijana [19].

Wydajność (przepustowość) może być oszacowana za pomocą kosztów strat czasu wynikających z konieczności odnowy oznakowania poziomego. Koszty strat czasu, powstających w trakcie aplikowania oznakowania poziomego na drodze, które wynikają z ograniczenia przepustowości (zamknięcie niektórych pasów ruchu) w analizie LCC, zastosowano m.in. w pracy Zhanga [19] - pominięto jednak zmienność jednostkowych strat czasu w zależności od zastosowanego materiału oznakowania.

Efektywność ekonomiczna to zdolność do takiego wykorzystania posiadanych zasobów, aby w sposób najbardziej skuteczny oraz najmniej marnotrawny osiągnąć dany 
cel. Efektywność ekonomiczna może być oceniona za pomocą wartości zaktualizowanej netto, wewnętrznej stopy zwrotu czy też analizy kosztów i korzyści, która była zastosowana w oznakowaniu poziomym [11]. Zastosowanie analizy kosztów i korzyści (stosunek kosztów do korzyści BCR) w [11] pozwoliło oszacowań korzyści, jakie niesie za sobą m.in. stosowanie oznakowanie z masy termoplastycznej $(\mathrm{BCR}=130$; obszar zamiejski).

\subsection{Ogólny model szacowania kosztów metodzie LifeRoSE}

W ramach projektu badawczego RID 3B LifeRoSE opracowano ogólną koncepcję metody szacowania kosztów cyklu życia drogowych środków brd na drogach krajowych.

Podstawę metody stanowi prosty matematyczny model szacowania kosztów cyklu życia (LCC) drogowych środków brd opisany wzorem (1). Przyjęto również strukturę podziału kosztów funkcjonowania drogowych środków brd, które przedstawiono na rys. 1 .

$$
L C C=K S+\sum_{i=1}^{T} \frac{K Z_{i}}{(1+a)^{T}}
$$

gdzie:

$L C C$ - koszty cyklu życia funkcjonowania drogowych środków brd, $K S$ - koszty stałe, $K Z$ - koszty zmienne, $a$ - stopa dyskontowa, $i$ - rok analizy, $T$ - okres analizy (długość cyklu życia).

Koszty stałe KS są to wydatki ponoszone w pierwszym cyklu życia obiektu, tj. wydatki ponoszone przez inwestora (zrządzającego drogą) na przygotowanie, zakup materiałów i wbudowanie urządzeń na analizowanej drodze. Natomiast koszty zmienne KZ są to nakłady ponoszone na utrzymanie urządzenia oraz koszty użytkowników drogi związane z funkcjonowaniem urządzenia w kolejnych latach życia obiektu. Opracowana metoda może być stosowana do szacowania kosztów funkcjonowania analizowanego urządzenia (bariery drogowe, oznakowanie poziome itp.) w cyklu życia analizowanego odcinka drogi w zależności od zbioru parametrów opisujących jego poszczególne cechy funkcjonalności, takie jak: trwałość, wydajność, bezpieczeństwo, a także efektywność ekonomiczną. 


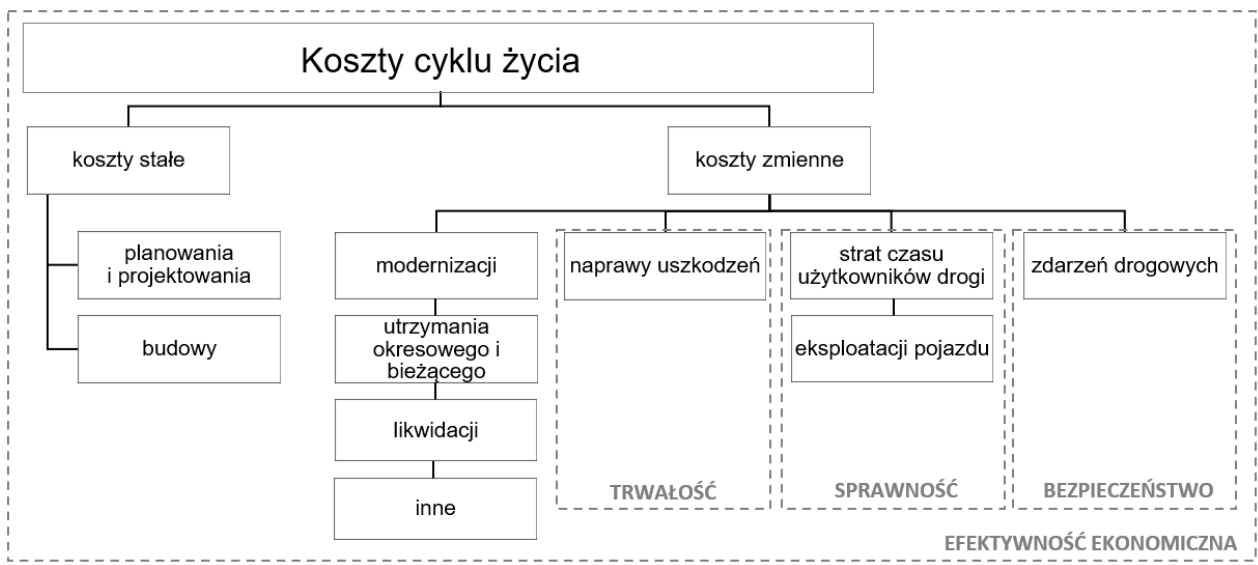

Rys. 1. Składowe koszty cyklu życia drogowych środków brd i miary funkcjonalności

Trwałość oceniana jest poprzez koszty naprawy uszkodzeń (odnowy) urządzenia brd. Koszty te generowane są w przypadku urządzeń brd oraz oznakowania pionowego w wyniku najechania pojazdu na drogowe środki brd, natomiast w przypadku oznakowania poziomego są to koszty związane $\mathrm{z}$ koniecznością jego odnowy związana $\mathrm{z}$ utratą minimalnych parametrów funkcjonalnych.

Wydajność drogowych środków brd określona została za pomocą kosztów strat czasu i kosztów eksploatacji pojazdów. Koszty strat czasu użytkowników związane są $\mathrm{z}$ najechaniem pojazdu na urządzenia brd lub zajęciem pasa drogi w związku z odnową oznakowania. Koszty eksploatacji pojazdów to dodatkowe koszty zużycia paliwa i pojazdów wynikające z wydłużenia czasu podróży w związku z wystąpieniem zdarzenia.

Bezpieczeństwo oceniane jest za pomocą kosztów zdarzeń drogowych, które można zdefiniować jako koszty ponoszone w wyniku zajścia zdarzenia drogowego z drogowymi środkami brd i jego konsekwencjami.

\section{Zastosowanie metody LifeRoSE do oceny funkcjonowania oznakowania poziomego drogi}

Koncepcja metody. Metodę LifeRoSE dostosowano do szacowania kosztów funkcjonowania oznakowania poziomego dróg poprzez pominięcie części składowych kosztów: utrzymania okresowego i bieżącego, eksploatacji, zdarzeń drogowych oraz likwidacji, z uwagi na ograniczony zakres danych dotyczących oznakowania poziomego w możliwych do uzyskania. Model szacowania kosztów funkcjonowania oznakowania poziomego w metodzie LifeRoSE, po rozwinięciu wzoru (1) przyjmuje postać opisaną wzorem (2): 


$$
L C C_{m}=K_{p l}+K_{b u}+\sum_{i=1}^{T} \frac{K_{n a_{i}}+K_{s t_{i}}}{(1+a)^{T}}
$$

gdzie:

$L C C m$ - koszty funkcjonowania oznakowania poziomego w cyklu życia analizowanego odcinka drogi, $K p l$ - koszty planowania, $K b u$ - koszty aplikacji (wbudowania), Kna koszty odnowy (naprawy), Kst - koszty strat czasu , $a$ - stopa dyskontowa, $i$ - rok analizy, $T$ - okres analizy.

Metoda badań. Do oceny funkcjonalności oznakowania poziomego zastosowano metodę LifeROSE. Do badań analitycznych przyjęto następujące założenia:

1. Obiektem badań analitycznych był odcinek drogi klasy $\mathrm{S}$ o długości $1 \mathrm{~km}$, na którym zastosowano oznakowanie poziome w postaci ciągłej linii krawędziowej.

2. Przyjęto cztery rodzaje oznakowania poziomego drogi, wykonanego z:

a) masy termoplastycznej nakładanej o powierzchni kulek szklanych w masie $<30 \%$,

b) masy termoplastycznej nakładanej o powierzchni kulek szklanych w masie $>30 \%$,

c) masy chemoutwardzalnej natryskowej,

d) masy chemoutwardzalnej nakładanej.

3. Przyjęto średniodobowe natężenie ruchu pojazdów $S R D=10$ tys. poj./dobę na pas.

4. Przyjęto średni okres trwałości $\mathrm{TR}_{\mathrm{m}}$ poszczególnych rodzajów oznakowania od natężenia ruchu pojazdów SDR na podstawie badań przeprowadzonych $\mathrm{w}$ ramach projektu RID 3B [7].

5. Przyjęto aktualną stopę dyskontową za rok 2019, a $=2,87 \%$.

6. Przyjęto średni czas aplikacji (wbudowania) oznakowania na drodze jako czas trwania zdarzenia (do obliczeń strat czasu użytkowników drogi).

7. Założono, że koszty odnowy oznakowania w kolejnym roku są równe kosztom pierwotnej aplikacji.

8. Przyjęto cykl życia odcinka drogi $\mathrm{T}=30$ lat.

Do oceny efektywności ekonomicznej wybranych rodzajów oznakowania poziomego przyjęto dwa wskaźniki:

1. koszt funkcjonowania wybranych rodzajów oznakowania poziomego $\mathrm{LCC}_{\mathrm{m}}$,

2. wskaźnik efektywności ekonomicznej $W_{m, i}$ obliczany wg wzoru (3):

$$
W E_{m, i}=\frac{L C C_{m, i}}{L C C_{m, \min }}
$$

gdzie:

$W E m, i$ - wskaźnik efektywności ekonomicznej $i$-tego rodzaju oznakowania poziomego, $L C C m, i$ - koszty cyklu życia $i$-tego rodzaju oznakowania poziomego, LCCm,min minimalne koszty cyklu życia, $i$ - rodzaj oznakowania poziomego.

Wyniki obliczeń dla średnich wartości przyjętych w założeniach do badań przedstawiono w tabeli 1 . 
Tabela 1

Koszty cyklu życia oznakowania poziomego

\begin{tabular}{|c|c|c|c|c|c|c|}
\hline \multirow[t]{2}{*}{$\begin{array}{c}\text { Rodzaj } \\
\text { materiału } \\
\text { i }\end{array}$} & $\begin{array}{c}\text { Założony } \\
\text { okres } \\
\text { trwałości } \\
\text { TR }_{\mathrm{m}}\end{array}$ & $\begin{array}{c}\text { Koszt cyklu } \\
\text { życia } \\
\mathrm{LCC}_{\mathrm{m}}\end{array}$ & $\begin{array}{c}\text { Koszt } \\
\text { instalacji } \\
\mathrm{K}_{\mathrm{pl}}+\mathrm{K}_{\mathrm{bu}}\end{array}$ & $\begin{array}{c}\text { Koszty } \\
\text { odnowy } \\
\mathrm{K}_{\text {na }}\end{array}$ & $\begin{array}{c}\text { Koszty strat } \\
\text { czasu } \\
\mathrm{K}_{\text {st }}\end{array}$ & $\begin{array}{c}\text { Wskaźnik } \\
\text { efektywności } \\
W_{\mathrm{m}}\end{array}$ \\
\hline & (lat) & $\begin{array}{c}\text { (tys. PLN/30 } \\
\text { lat) }\end{array}$ & $\begin{array}{c}\text { (tys. PLN/ } \\
\text { 30lat) }\end{array}$ & (tys. PLN/ 30lat) & $\begin{array}{c}\text { (tys. PLN/30 } \\
\text { lat) }\end{array}$ & $(-)$ \\
\hline $\mathrm{a}$ & 3 & 39,0 & 5,2 & 33,5 & 0,3 & 1,2 \\
\hline $\mathrm{b}$ & 4 & 32,5 & 5,8 & 26,5 & 0,2 & 1,0 \\
\hline $\mathrm{c}$ & 1 & 110,2 & 5,0 & 98,4 & 6,8 & 3,4 \\
\hline d & 2 & 82,3 & 7,4 & 72,8 & 2,1 & 2,5 \\
\hline
\end{tabular}

Na podstawie przeprowadzonej analizy stwierdzono, że:

1. najmniejszymi kosztami cyklu życia $\mathrm{LCC}_{\mathrm{m}}$ (32,5 tys. PLN) i najlepszym wskaźnikiem efektywności ekonomicznej $\left(\mathrm{WE}_{\mathrm{m}}=1,0\right)$ charakteryzuje się odcinek analizowanej drogi, na którym oznakowanie wykonano z masy termoplastycznej nakładanej z więcej niż $>30 \%$ kulek szklanych w masie, dlatego jest materiałem zalecanym do aplikacji dla podanego powyżej przykładu; droga ta charakteryzuje się również sprawnością, a masa dużą trwałością,

2. największymi kosztami cyklu życia LCC $_{m}$ (110,2 tys. PLN) i najgorszym wskaźnikiem efektywności ekonomicznej $\left(\mathrm{WE}_{\mathrm{m}}=3,4\right)$ charakteryzuje się odcinek analizowanej drogi, na którym oznakowanie wykonano z masy chemoutwardzalnej natryskowej. Mimo że jest najtańszy w aplikacji, to ma małą trwałość i generuje duże straty czasu użytkowników drogi, przez co nie jest zalecany do aplikacji dla analizowanego odcinka drogi,

3. największy udział w kosztach cyklu życia mają koszty odnowy ok. 90\% wszystkich kosztów.

\section{Badanie wpływu wybranych czynników na koszty cyklu życia odcinka drogi z wybranym rodzajem oznakowania poziomego}

W poprzednim rozdziale wykazano, że rodzaj użytego oznakowania poziomego drogi wpływa istotnie na koszt cyklu życia analizowanego odcinka. Poniżej przedstawiono wyniki badań wpływu wybranych czynników: wielkości stopy dyskontowej a, wielkości natężenia ruchu na drodze SDR i trwałości oznakowania $\mathrm{TR}_{\mathrm{m}}$. Do badań analitycznych zastosowano również metodę LifeRoSE, przyjmując następujące założenia dodatkowe: 
1. Wybrano dwa rodzaje oznakowania poziomego:

a) do badań wpływu stopy dyskontowej a i wielkości ruchu drogowego SDR przyjęto nawierzchnię wykonaną z masy chemoutwardzalnej natryskowej (nr $3 \mathrm{w}$ poprzednim badaniu),

b) do badań wpływu okresu trwałości TRm oznakowań przyjęto nawierzchnię wykonaną z masy termoplastycznej nakładanej o powierzchni kulek szklanych w masie $<30 \%$ (nr $1 \mathrm{w}$ poprzednim badaniu).

2. Przyjęto zmienne natężenie ruchu pojazdów SDR w zakresie od 5,0 do 20,0 tys. poj./dobę (pas ruchu).

3. Przyjęto średni okres trwałości $\mathrm{TR}_{3}=1 \mathrm{rok}, \mathrm{TR}_{1}=2-4$ lat.

4. Przyjęto stopę dyskontową a w zakresie $1,0-6,0 \%$.

5. Pozostałe założenia przyjęto podobne jak w poprzednim badaniu (rozdz. 3).

Wyniki badań wskazują, że wzrost stopy dyskontowej wpływa na spadek kosztów cyklu życia $\mathrm{LCC}_{\mathrm{m}}$ badanego odcinka drogi oznakowanego chemoutwardzalną masą natryskową (rys. 2). Im większa stopa dyskontowa, tym mniejszy zakres kosztów przyjmuje się do oceny (tym większa waga przyjmowana jest dla początkowego okresu analizy). Ma to znaczenie dla dłuższych okresów analizy, np. koszty cyklu życia w 10. roku funkcjonowania badanego odcinka drogi oznakowanego masą chemoutwardzalną różnią się o ok. $15 \%$, a w 30 . roku o ok. $40 \%$.

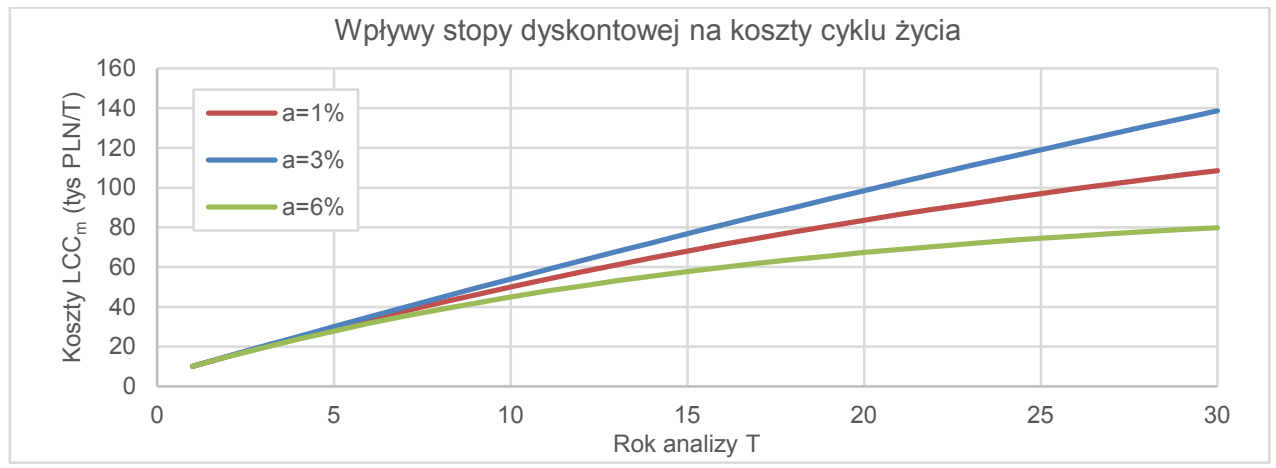

Rys. 2. Wpływ stopy dyskontowej i czasu trwania cyklu życia $\mathrm{T}$ na koszty cyklu życia $\mathrm{LCC}_{\mathrm{m}}$ masy chemoutwardzalnej

Wzrost natężenia ruchu pojazdów SDR wpływa na wzrost kosztów cyklu życia $\mathrm{LCC}_{\mathrm{m}}$ odcinka drogi oznakowanego chemoutwardzalną masą natryskową (rys. 3). Wraz ze wzrostem natężenia ruchu pojazdów zmniejsza się okres trwałości oznakowania. Rosną przede wszystkim koszty strat $\mathrm{K}_{\text {st }}$ czasu użytkowników ruchu podczas aplikacji (odnowy) oznakowania. W wyniku badań stwierdzono, że koszty strat czasu, mają znikomy wpływ na całkowite koszty cyklu życia w przypadku wykonywania aplikacji (odnowy) oznakowania przy małym natężeniu ruchu (ok. 5\% kosztów całkowitych). Natomiast przy większym natężeniu ruchu SDR > 10 tys. poj. /dobę, udział kosztów strat czasu wzrasta 
dość gwałtownie i może być parametrem decydującym o wysokości kosztów cyklu życia funkcjonowania odcinka drogi z oznakowaniem poziomym.

Wzrost okresu trwałości $\mathrm{TR}_{\mathrm{m}}$ wpływa na zmniejszenie kosztów cyklu życia $\mathrm{LCC}_{\mathrm{m}}$ odcinka drogi oznakowanego masą termoplastyczną nakładaną o powierzchni kulek szklanych w masie $<30 \%$ (rys. 4). Wraz ze wzrostem okresu trwałości oznakowania zmniejsza się częstość aplikacji oznakowania na drodze oraz częstość występowania utrudnień na drodze (mniejsze straty czasu).

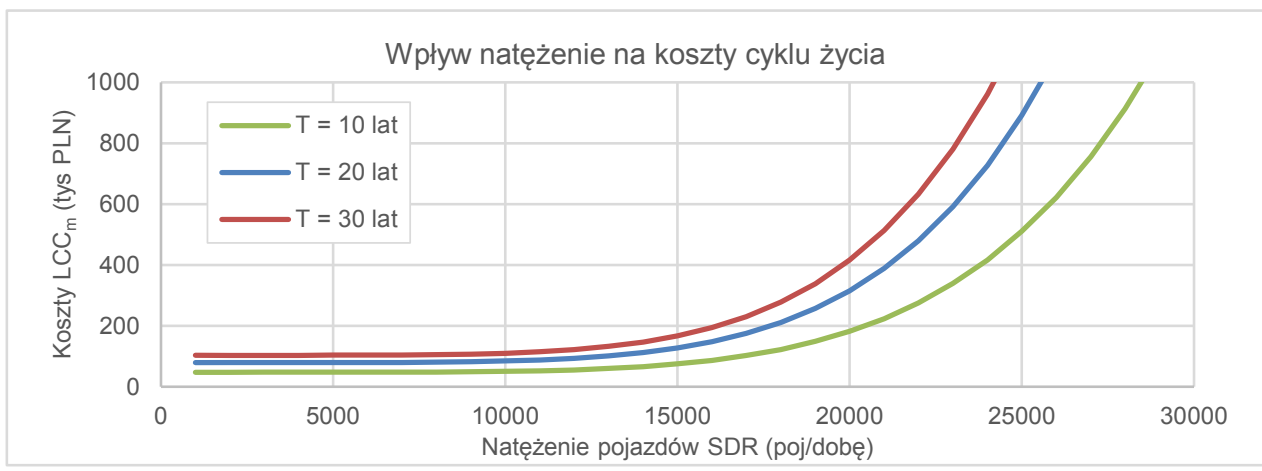

Rys. 3. Wpływ natężenia ruchu SDR i okresu cyklu życia $\mathrm{T}$ na koszty cyklu życia masy chemoutwardzalnej $\mathrm{LCC}_{\mathrm{m}}$

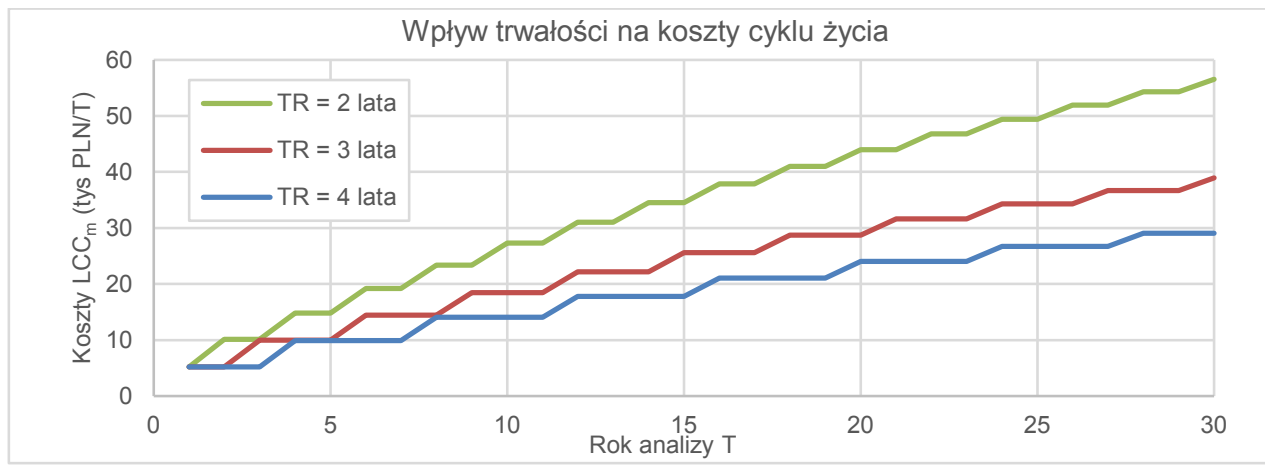

Rys. 4. Wpływ okresu trwałości masy termoplastycznej $\mathrm{TR}_{\mathrm{m}} \mathrm{i}$ okresu cyklu życia $\mathrm{T}$ na koszty cyklu życia analizowanego odcinka drogi $\mathrm{LCC}_{\mathrm{m}}$

$\mathrm{W}$ badaniach dla uproszczenia analizy przyjęto średni okres trwałości $\mathrm{TR}_{\mathrm{m}}$ niezależnie od analizowanego natężenia ruchu pojazdów. W rzeczywistości okres trwałości oznakowania poziomego zależy od natężenia ruchu, a w szczególności od liczby przejść koła pojazdu po nawierzchni drogi z naniesionym oznakowaniem. Poza tym, jak wykazano w przeglądzie literatury, na okres trwałości wpływa wiele innych parametrów. W przypadku zastosowania metody $\mathrm{LCC}_{\mathrm{m}}$ do wyboru konkretnego rodzaju materiału 
należałoby w celu ustalenia okresu trwałości zweryfikować jakość materiałów oraz określić warunki, w jakich będą funkcjonować.

\section{Podsumowanie}

Metoda szacowania kosztów cyklu życia daje możliwość połączenia aspektów ekonomicznych, technicznych i funkcjonalnych ocenianego obiektu oraz stanowi dobre narzędzie do oceny funkcjonalności drogowych środków brd. Umożliwia porównanie wybranych funkcji użyteczności - trwałości, wydajności, bezpieczeństwa wybranych konstrukcji drogowych za pomocą kosztów.

Zaprezentowana metoda LifeROSE jest uniwersalna i może być stosowana do szacowania kosztów cyklu życia odcinków dróg oraz oceny efektywności ekonomicznej wybranych drogowych środków brd zastosowanych na analizowanej drodze. Pozwala to na wybór optymalnego rozwiązania pod względem funkcjonalnym.

Metoda ta może być również wykorzystywana jako narzędzie badawcze do badania wpływu wybranych czynników na zmianę kosztów cyklu życia obiektu.

Dokładność oszacowania kosztów cyklu życia analizowanego obiektu wymaga zebrania dużego zbioru danych o kosztach cząstkowych budowy i eksploatacji poszczególnych elementów obiektu. Pomocne mogą być modele zależności tych kosztów od wielkości poszczególnych czynników, wpływających na funkcjonowanie analizowanego obiektu jak np. trwałość, bezpieczeństwo ruchu, straty czasu.

W dalszych pracach przewiduje się opracowanie takich modeli oraz uwzględnienie wpływu zmian jakości oznakowania poziomego drogi na bezpieczeństwo ruchu drogowego i uwzględnienie tego czynnika w kosztach funkcjonowania drogi przy zastosowaniu oznakowania poziomego wykonanego z różnych materiałów.

\section{Literatura}

1. Babić D., Ščukanec A., Babić D., Fiolić M.: Model for predicting road markings service life. Baltic Journal of Road and Bridge Engineering, vol. 14, no. 3, 2019.

2. Dz.U. 2003 nr 220 poz. 2181, Rozporządzenie Ministra Infrastruktury w sprawie szczegółowych warunków technicznych dla znaków i sygnałów drogowych oraz urządzeń bezpieczeństwa ruchu drogowego i warunków ich umieszczenia na drogach.

3. Dziaduch I.: Analiza kosztów okresu istnienia (LCC) obiektu technicznego w aspekcie jego niezawodności. Logistyka, rocznik 2011, nr 2, 2011.

4. Jamroz K.: Metoda zarządzania ryzykiem w inżynierii drogowej, Gdańsk 2011.

5. Jamroz K., Gobis A., Kristowski A., Grzyl B.: Proposed method for estimating the costs of safety barrier life cycle. MATEC Web of Conferences, vol. 231, 2018. 
6. Jeliński Ł., Jamroz K., Jamroz J., Antoniuk M.: Functionality of road safety devices - identification and analysis of factors. MATEC Web of Conferences, vol. 122, 2017.

7. Jeliński L., Wachnicka J., Jamroz J., Kalisz M., Kaźmierczak P., Lusa R., et al.: Testing the durability and function of road traffic management devices. MATEC Web Conferences, vol. 122, 2017.

8. Karim H., Magnusson R., Natanaelsson K.: Life-Cycle Cost Analyses for Road Barriers. Journal of Transportation Engineering, vol. 138, iss.7, 2012.

9. Kopf J.: Reflectivity of Pavement Markings: Analysis of Retroreflectivity Degradation Curves, 2004.

10. Malyuta D.A.: Analysis of factors affecting pavement markings and pavement marking retroreflectivity in Tennessee Highways, University of Tennessee, 2015.

11. Miller T.R.: Benefit-cost analysis of lane marking. Transportation Research Record, 1334, 1993.

12. Monfette M.: Impact of snow removal operations on thermoplastic pavement markings. Air Force Institute of Technology, 2011.

13. Mull D.M., Sitzabee W.: Paint Pavement Marking Performance Prediction Model. Journal of Transportation Engineering, vol. 138, 2012.

14. Needham J.: Degradation modeling of polyurea pavement markings, Air Force Institute of Technology, 2011.

15. Onyango M.A., Malyuta D., Owino J., Chimba D.: Verification of pavement marking degradation models using eastern Tennessee pavement marking retroreflectivity data. 2nd Pan African Int. Conf. Sci., Comput. and Telecommun, 2014.

16. PN-EN 60300-3-3, Zarządzanie niezawodnością część 3-3: Przewodnik zastosowań Szacowanie kosztu cyklu życia, 2017.

17. Tułecki A., Szkoda M.: Koszt trwałości LCC jako model decyzyjny modernizacji pojazdów szynowych. Zeszyty Naukowe Instytutu Pojazdów, z.1/64, 2007.

18. Williams G.L.: Whole Life Cost-Benefit Analysis for Median Safety Barriers. Task 1-Relocation of service, 2007.

19. Zhang Y., Wu D.: Methodologies to Predict Service Lives of Pavement Marking Materials. Journal of the Transportation Research Forum, vol. 45, no. 3, 2006. 